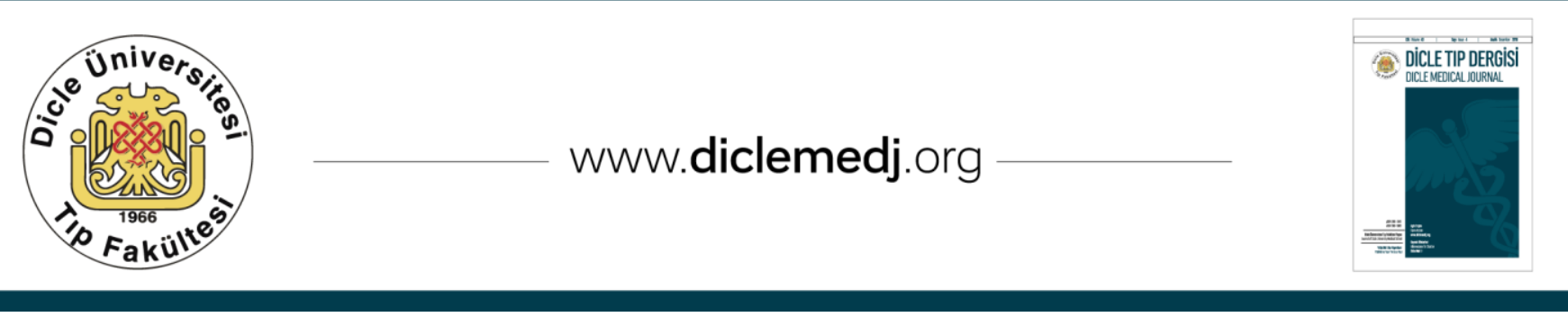

Original Article/Özgün Araştırma

\title{
Effect of clinical autonomic dysfunction on cognitive functions in Parkinson's disease
}

\author{
Dursun Aygun', Cetin Kursad Akpinar'2, Serpil Yon ${ }^{3}$, Musa Kazım Onar1 \\ 1 Ondokuz Mayis University, Medical Faculty, Department of Neurology, Samsun, Turkey \\ 2 Training and Research Hospital, Neurology Clinic, Samsun, Turkey \\ 3 Carsamba State Hospital, Neurology Service, Samsun, Turkey
}

Received : 27.10.2016; Revised: 16.06.2017; Accepted : 27.07.2017

\begin{abstract}
Objective: Parkinson's disease (PD) is a chronic progressive neurodegenerative disorder characterized by tremor, rigidity, bradykinesia, and postural instability. PD also involves nonmotor manifestations such as autonomic failure, cognitive disorders, and sleep disorders. These clinical characteristics are not identical in severity, frequency, and onset time in all PD patients. We assessed whether there is a negative effect on cognition of clinical autonomic dysfunction in PD patients.

Methods: This prospective study includes 37 PD patients with autonomic failure. From each patient, a questionnaire (SCOPA-AUT) including symptoms associated with clinical autonomic dysfunction such as constipation, urinary incontinence, orthostatic hypotension, and hyperhydrosis was obtained and the patient's clinical condition was rated on the Hoehn and Yahr (H-Y) scale in the ON-medication state. The patients' cognitive function was assessed by the Mini-Mental State Examination (MMSE), Blessed score, Frontal Assessment Battery (FAB), and Digid Span Test (DST) (forward, reverse). Cognitive test scores were compared with SCOPA-OUT scores.

Results: Mean age was $66,5 \pm 11.2$ years. There was no correlation between cognitive test scores and SCOPA-OUT scores $(p>0.05)$. However, H-Y scores were negatively correlated with the DSTf, DSTr, FAB, and MMSE scores (p50.005, r:-0.451; p50.025, r: -0.367; p50.040, r: -0.340; p50.044, r5-0.333, respectively).

Conclusions: According to our results, clinical autonomic dysfunction did not seem to have an effect on cognition. In addition, severity of cognitive dysfunction showed a strong negative correlation with the stage of disease.
\end{abstract}

Keywords: Blessed score, Clinical autonomic dysfunction, Cognitive test, Parkinson's disease, SCOPA-AUT

DOI: $10.5798 /$ dicletip.338976

Yazışma Adresi / Correspondence: Cetin Kursad Akpinar, Training and Education Hospital, Neurology clinic, Samsun, Turkey e-mail: $\underline{\text { dr ckakpinar@hotmail.com }}$ 


\section{Parkinson hastalarındaki klinik otonomik disfonksiyonun kognitif fonksiyonlar üzerine etkisi}

Özet

Giriș: Parkinson hastalığı (PH) tremor, rijidite, bradikinezi ve postural instabilite ile karakterize kronik dejeneratif ilerleyici bir hastalıktır. PH ayrıca otonomik yetmezlik, kognitif bozukluk ve uyku bozukluğu gibi nonmotor bulguları da içerir. Bu klinik bulgular PH'lığının başlangıç zamanı, sıklık ve şiddetine göre değerlendirilmemiştir. Biz PH'daki otonomik disfonksiyonun kognisyon üzerine negatif etkisi olup olmadığını değerlendirdik.

Yöntemler: Bu prospektif çalışmaya otonomik yetmezliği olan 37 PH dahil edildi. Her bir hasta konstipasyon, uriner inkontinans, ortostatik hipotansiyon ve hiperhidrozis gibi klinik otonomik disfonksiyon ile ilișkili semptomları içeren SCOPA-AUT anketi ve hastaların on durumundaki klinik durumu Hoehn Yahr (H\&Y) skalası ile elde edildi. Hastaların kognitif fonksiyonu mini mental durum muayenesi (MMSE), blessed skoru, frontal değerlendirme ölçeği (FAB), ileri (DSTf) ve geri (DSTr) sayı testi ile değerlendirildi. Kognitif test skorları SCOPA-AUT skoru ile karşılaştırıldı.

Bulgular:Yaş ortalaması 66,5 \pm 11.2 yıldı. Kognitif test skoru ve SCOPA-AUT skoru arasında istatiksel bir ilişki yoktu ( $p>0.05$ ). Fakat H-Y skoru ile DSTf, DSTr, FAB ve MMSE skoru arasında negatif bir korelasyon vardı ( $p=0.005, r:-0.451$; $\mathrm{p}=0.025, \mathrm{r}:-0.367 ; \mathrm{p}=0.040$, $\mathrm{r}:-0.340 ; \mathrm{p}=0.044, \mathrm{r}:-0.333$, sirasiyla).

Sonuçlar: Bizim sonuçlarımıza göre, klinik otonomik disfonksiyonun kognisyon üzerine bir etkisi olmadığıdır. İlave olarak kognitif fonksiyonun ciddiyeti hastalığın evresi ile güçlü negatif bir korelasyon gösterdi.

Anahtar kelimeler: Blessed skoru, klinik otonomik disfonksiyon, kognitif test, Parkinson hastalığı, SCOPA-AUT

\section{INTRODUCTION}

Parkinson's disease (PD) is a chronic progressive neurodegenerative disease which includes motor signs and symptoms such as rigidity, bradykinesia, rest tremor and balance disorder ${ }^{1}$. Parkinson's disease is a neurodegenerative disease which courses especially with the loss of dopaminergic cells in substantia nigra (SN). A great number of mechanisms have been put forward in its pathogenesis $^{1,2}$. Non-motor symptoms of this disease are not well defined as motor symptoms. Non-motor symptoms can be seen in the early stages of the disease or years before motor symptoms start ${ }^{1}$. Non-motor features include neuropsychiatric disorder, sleep disorder, autonomic dysfunction, pain and sensory impairment ${ }^{2}$. As the disease progresses, the variety of these symptoms increase $^{3}$. As in motor symptoms, non-motor symptoms significantly affect life quality and physical activity ${ }^{4}$. While motor symptoms respond well to dopaminergic treatment, non- motor symptoms do not show an obvious improvement. Although there are studies in literature which show a directly proportional association between motor response and PD dementia and autonomic dysfunction and advanced PD, there are also studies which support the opposite ${ }^{5,6}$. There are limited numbers of studies in literature which show the effect of autonomic deficiency on dementia. To the best of our knowledge, there are no studies directly assessing the association between autonomic dysfunction, cognitive function and dementia clinically. In this sense, we believe that our study will contribute to literature. In our study, we evaluated the effects of autonomic dysfunction clinically found in Parkinson's disease patients on cognitive functions.

\section{METHODS}

The hospital research ethics boards approved this study, and informed written consent was obtained from all participants. 
60 Parkinson's patients were assessed for the study. 23 were excluded and 37 patients were included in the study. The diagnosis of Parkinson's disease was made by a neurologist who is an expert in the field and the related tests were made by another neurologist who is also experienced in the field.

The study included patients who were registered in $* * *$, Neurology Parkinson's and Motion Sicknesses Polyclinic with a diagnosis of Parkinson's disease and who were found to have clinical autonomic dysfunction with the Scales for Outcomes in Parkinson's disease Autonomic (SCOPA- AUT) questionnaire. Cognitive tests and SCOPA- AUT questionnaire were administered in the pre-stage (within the six hours following dopaminergic drug intake). Cognitive functions were assessed through Mini Mental State Examination test ${ }^{2}$, Blessed test6, Frontal Evaluation Test $^{7}$ number sequence test $^{3}$. Clinical presence and severity of autonomic involvement was determined with SCOPA- AUT questionnaire ${ }^{8}$. Hoehn and Yahr (H\&Y) scale was administered to assess the disease severity ${ }^{9}$. The patients who had moderate and severe depression according to Geriatric Depression Scale, those who had visual hallucinations, patients who had diabetes mellitus for more than five years, smokers, patients who were taking medication that can affect autonomic function and those who had 4 and 5 Hoenh-Yahr staging were excluded from the study.

Mini Mental State Examination test: 30 points in total (30 is the best), the test consists of items that measure time and space orientation (10 points), memory (3 points for recording and 3 points for remembering, 6 points in total), attention ( 5 points), language ( 8 points) and visual-spatial functions (1 point) ${ }^{2}$.

Blessed test: In order to reach a total of 28 points (28 is the worst), error numbers in each item are multiplied with pre-determined weighted coefficients. Following the two time orientation items (year and month), an imaginary name-surname and address of 5 elements are given to be memorized as memory item. After a time orientation (hour of the day) and two attention items (counting down from 20 one by one and counting the months from backwards) are placed within the delay time, the address is scored with free recall6.

Frontal Evaluation Test: It is a test which can be administered in a short time and it is used in the assessment of frontal lobe functions. It consists of 6 sub-divisions that give a total possible score between 0 and 18. Sub-divisions are similarities (conceptualization), word fluency (mental flexibility), motor series (programming), contradicting instructions (sensitivity to interference), do-don't do (inhibitory control) and catch behavior (environmental autonomy). High scores taken from the test mean better performance ${ }^{7}$.

Geriatric Depression Scale: A score of over five can correspond to depression; it should be evaluated with the patient's clinic.

Number sequence test: It is the most commonly used attention/short-term memory test. It consists of two parts as number range, forward and backward counting range. In both, the subject is read random numbers with breaks of one second in-between, the numbers increase at each try and the subject is asked to repeat with the same order. For both parts, the number of the first series out of the two consequent series the subject fails forms the number range. For normal individuals, the lower limit is generally accepted as 6 forward and 4 backward ${ }^{3}$.

\section{RESULTS}

Of the 37 patients included in the study, 18 were male and 19 were female and their averages of age were 66,53 \pm 11.2 (46-79). Average age for disease onset was $60,61 \pm 6,14$ and the average duration of disease was 
4,87 $\pm 1,91$ years. Mean MMSE score and Blessed score were 23.6 (15-30) and 15,8 (3-26), respectively. $\mathrm{H} \& \mathrm{Y}$ clinical stage averages of the cases was $1,37 \pm 0,49$. Mean total SCOPA-AUT score was 12.8 and H\&Y stages did not correlate with SCOPA-AUT $(\mathrm{p}<0.05)$ (Table 1). There was no correlation between cognitive test scores (MMSE, FAB, Blessed score, DSTf, DSTr) and SCOPA-OUT scores ( $p>0.05$ ) (Table 2). However, $\mathrm{H}-\mathrm{Y}$ scores negatively correlated with the DSTf, DSTr, FAB, and MMSE scores $(\mathrm{p}=0.005, \mathrm{r}:-0.451 ; \mathrm{p}=0.025, \mathrm{r}:-0.367 ; \mathrm{p}=0.040$, $\mathrm{r}:-0.340 ; \quad \mathrm{p}=0.044, \quad \mathrm{r}=-0.333$, respectively) (Table 3). In addition, there was a positive correlation between the Blessed score with age $(\mathrm{r}=0.41, \mathrm{p}<0.01)$, disease duration $(\mathrm{r}=0.45, \mathrm{P}$ $<0.05)$ and H\&Y score $(r=0.37, p<0.05)$. No significant association was found between the side on which the disease started and SCOPAAUT and cognitive tests. Autonomic dysfunction may be present from disease onset, whereas the rate of cognitive decline increases with disease progression.

Table 1: Clinical characteristics of the patients, mean $\pm \mathrm{SD}$

\begin{tabular}{|l|l|}
\hline Number of patient (M,F) & $37(18,19)$ \\
\hline Mean Age & $66,53 \pm 11.2$ \\
\hline Mean disease duration & $4,87 \pm 1,91$ \\
\hline Mean disease onset age & $60,61 \pm 6,14$ \\
\hline Hoehn-Yahr stage & $1,37 \pm 0,49$ \\
\hline SCOPA-AUT test & $12.8(5-34)$ \\
\hline MMSE test & $23.6(15-30$ \\
\hline Blessed score & $15,8(3-26)$ \\
\hline Digid span forward & $5,1(3-7)$ \\
\hline Digid span reverse & $2.0(1-4)$ \\
\hline Frontal assesment battery & $10.8(4-17)$ \\
\hline
\end{tabular}

M:Male; F:Female; SCOPA-AUT: the Scales for Outcomes in Parkinson's disease - Autonomic

\section{DISCUSSION}

Although the mechanisms in the pathogenesis of Parkinson's disease are not fully understood, it is thought to occur as a result of chain of events that emerge with disorders in the protein processing triggered by genetic factors and environmental factors, oxidative stress, mitochondrial disorder, excitotoxicity, inflammation and changes in the immune system ${ }^{10-14}$.

Initially, genetic factors were not thought to be effective in PD, it was thought to be a sporadic disease. With the findings in studies that in $20 \%$ to $25 \%$ of sporadic PD cases at least one of the first degree relatives had PD, PD risk is increased in individuals whose first degree relatives had $P D$, genetic factors in twins were important for early onset PD and the discovery of genes related with familial PD, genetic factors gained importance ${ }^{10-14}$.

Intracytoplasmic Lewy body accumulation and neuron dysfunction starts from olfactory bulb and dorsal vagal nucleus and then involves the cortex. Clinical findings are known to start after the disappearance of a specific rate of dopaminergic cells which include melanin in $\mathrm{SN}^{10}$. Cognitive dysfunction and dementia develop with the accumulation of Lewy bodies in limbic cortex and frontal neocortical regions and the decrease in frontal dopaminergic cortical projection. Executive functions are influenced based on basal ganglions being affected and the decrease in the dopaminergic input to prefrontal cortex ${ }^{11}$. Autonomic dysfunction develops based on the sympathetic ganglion and peripheral autonomous nerve system as well as synuclein pathology in dorsal vagal nucleus, hypothalamus and neurons in the intermediolateral nucleus of the spinal cord. In addition, cardiac sympathetic fiber exposure can cause orthostatic hypotension and postural hypotension while parasympathetic fiber exposure can cause changes in heart rate ${ }^{12}$. One study showed 
degeneration in vagal nerve, spinal cord and celiac ganglion. This explained the clinical variety in motor and non-motor findings ${ }^{13}$. Another study showed that non-motor symptoms were seen frequently and especially in the advanced periods of the disease and they had serious effects on the quality of life. The same study reported that $21 \%$ of the patients were admitted with non-motor symptoms ${ }^{5}$. Non-motor features include neuropsychiatric disorder (depression, apathy/anhedonia, anxiety, frontal executive malfunction, dementia, psychosis), sleep disorder (insomnia, RUDB, daytime sleep), autonomic dysfunction (orthostatic hypotension, constipation, urogenital dysfunction, extreme sweating), pain and sensory impairment ${ }^{2}$.

Typical clinical feature of cognitive dysfunction is an executive dysfunction in the foreground (problem solving, attention, planning) and disorders in verbal fluency and visual-spatial skills since early periods. Memory impairment in early periods is not limbic ${ }^{12}$.

Different studies have reported the reasons which increase the development of dementia in
PD cases as mild cognitive dysfunction, postural instability, visual hallucinations, orthostatic hypotension, REM sleep behavioral disorder, speech and swallowing difficulty, symmetrical parkinsonism findings, gastrointestinal or urological dysfunction, male gender, depression, akinetic-rigid Parkinson and advanced age ${ }^{12,14}$.

With neuropsychological tests in PD, cognitive exposure was reported in rates between 20$83 \% 15$. In one study, cognitive dysfunction was found in 84\% of Parkinson's patients and as a result of a 15 year-long follow up of these patients, $47 \%$ were diagnosed with dementia ${ }^{16}$. Cognitive deterioration in PD may not always be parallel with motor performance. The tendency for negative association between UPDRS and MMSE scores in one study shows that cognitive dysfunction increases as motor disability increases ${ }^{17}$. In our study, a negative association was found between $\mathrm{H} \& \mathrm{Y}$ staging and MMSE while a positive association was found between Blessed test.

Table 2: Correlation between cognitive test scores and SCOPA-AUT score

\begin{tabular}{|l|l|l|l|l|l|l|}
\hline & MMSE & Blessed score & FAB & DSTf & DSTr & $\mathrm{p}$ value \\
\hline SCOPA-AUT & 23.6 & 15,8 & 10.8 & 5,1 & 2,0 & $\mathrm{p}>0,05$ \\
\hline
\end{tabular}

Table 3: Correlation between cognitive test scores and Heahn-Yahr stage

\begin{tabular}{|l|l|l|l|l|l|}
\hline & MMSE & Blessed score & FAB & DSTf & DSTr \\
\hline Heahn-Yahr & 23.6 & 15,8 & 10.8 & 5,1 & 2,0 \\
\hline$p$ value & $\mathrm{p}=0.044$ & $\mathrm{p}<0.01$ & $\mathrm{p}=0.040$ & $\mathrm{p}=0.005$ & $\mathrm{p}=0.025$ \\
\hline $\mathrm{r}$ value & $\mathrm{r}:-0.333$ & $\mathrm{r}=0.41$ & $\mathrm{r}:-0.340$ & $\mathrm{r}:-0.451$ & $\mathrm{r}:-0.367$ \\
\hline
\end{tabular}

Various studies have reported autonomous symptoms to occur at every stage of Parkinson's disease, in different severity and between $70-93 \% 18$. Clinical presence and severity of autonomous involvement in PD is assessed effectively and correctly by using SCOPA-AUT questionnaire ${ }^{8}$. SCOPA-AUT study showed association between the degree of motor exposure in PD and autonomous symptoms. Our study and the study of Oh et al. 
did not find any association between SCOPAAUT score and H\&Y staging ${ }^{19}$. In their study, Magerkurth et al. reported that one or more types of autonomous dysfunction could be seen and autonomous dysfunction was not associated with the duration and severity of the disease $^{20}$. Orthostatic hypotension is one of the most common symptoms of PD and it is seen with a rate of between $20-50 \%$ and it is more common in the advanced stages of the disease. In another study, no association was found between the disease severity and orthostatic hypotension $^{21}$. While there are studies which have not found an association between autonomic dysfunction and cognitive exposure $^{19,22}$, there are also studies which show an association between the two ${ }^{23}$. Prospective studies are needed to show the association between autonomic dysfunction and cognitive exposure.

There are limited numbers of studies about the effects of autonomous dysfunction on cognitive exposure. Unlike other studies, we assessed the clinical autonomous dysfunction in PD cases with detailed cognitive tests (Mini Mental State Examination test, Blessed scoring, Frontal Evaluation Test and number sequence test). In parallel with some studies in literature, no association was found between cognitive tests and SCOPA-AUT scores. However, while there was a negative association between cognitive test scores and H\&Y staging, there was a positive association between Blessed score and H\&Y staging. Autonomic dysfunction, which can easily be determined clinically with SCOPAAUT test, was found to occur in almost every stage of our cases. There are studies which show parallelism or non-parallelism between SCOPA-AUT test and H\&Y staging. Our study did not find a parallelism between the two.

When the results of studies were assessed together, it can be concluded that autonomic dysfunction can be seen in every stage of PD and it can cause cognitive exposure in some cases.

Since our study used a test which was proved to be efficient and reliable in finding out autonomous dysfunction, orthostatic hypotension and postural hypotension were not checked.

In addition to the cognitive tests we conducted, we believe that a study which assesses cognition with watch drawing and Montreal Cognitive Assessment: MoCA test, a study which assesses orthostatic hypotension and postural hypotension with holter through 24 hours of record in addition to SCOPA-AUT test, a study with many cases and in which cases are classified according to the drugs used and the duration of drug use will make valuable and important contributions to literature.

Declaration of Conflicting Interests: The authors declare that they have no conflict of interest.

Financial Disclosure: No financial support was received

\section{REFERENCES}

1. Aarsland D, Anderson K, Larsen JP, et al. Prevalence and characteristics of dementia in Parkinson disease. A 8-year prospective study. Arch Neurol. 2003; 60:38792.

2. Werner Poewe. Dysautonomia and Cognitive Dysfunction in Parkinson's Disease. Mov Disord. 2007; 22: 374-8.

3. Hughes AJ, Daniel SE, Kilford L, Lees AJ. Accuracy of clinical diagnosis of idiopathic Parkinson's disease: a clinico pathological study of 100 cases. J Neurol Neurosurg Psychiatry. 1992; 55:181-4.

4. Pfeiffer RF. Non-motor Parkinsonism. Parkinsonism Relat Disord. 2007; 13:211-20.

5. Chaudhuri KR, Naidu Y. Early Parkinson's disease and non-motor issues. J Neurol. 2008; 5:33-8.

6. Idiaquez J, Benarroch EE, Rosales $\mathrm{H}$, et al. Autonomic and Cognitive dysfunction in Parkinson's disease. Clin Auton Res. 2007; 17:93-8.

7. Dubois B, Slachevsky A, Litvan I, Pillon B. The FAB a frontal assessment battery at bedside. Neurology. 2000;55: 1621-6. 
8. Martínez-Martín P, Benito-León J, Burguera JA, et al. The SCOPA-Motor Scale for assessment of Parkinson's disease is a consistent and valid measure. J Clin Epidemiol. 2005; 58:674-9.

9. Hoehn M, Yahr M. Parkinsonism: onset, progression and mortality. Neurology. 1967; 17:427-42.

10. O'Sullivan SS, Williams DR, Gallagher DA, et al. Non motor symptoms as presenting complaints in Parkinson's disease: a clinicopathological study. Mov Disord. 2008; 23: 101-6.

11. Braak H, Del Tredici K, Rüb U, et al. Staging of brain pathology related to sporadic Parkinson's disease. Neurobiol Aging. 2003; 24:197-210.

12. Aarsland D, Kurtz MW. The epidemiology of dementia associated with Parkinson's disease. J Neurol Sci. 2010; 289:18-22.

13. Braak H, Rüb U, Del Tredici K. Cognitive decline correlates with neuropathological stage in Parkinson's disease. J Neurol Sci. 2006; 248:255-8.

14. Anang JBM, Gagnon JF, Bertrand JA, et al. Predictors of dementia in Parkinson disease. A prospective cohort study. Neurology. 2014; 83:1253-60.

15. Uc EY, McDermott MP, Marder KS, et al.; Parkinson Study Group DATATOP Investigators. Incidence of and risk factors for cognitive impairment in an early Parkinson disease clinical trial cohort. Neurology. 2009; 73: 1469-77.

16. Hely MA, Morris JG, Reid WG, Trafficante R. Sydney Multicenter Study of Parkinson's disease: non-L-doparesponsive problems dominate at 15 years. Mov Disord. 2005; 20:190-9.

17. Pillon B, Boller F, Levy R, Dubois B. Cognitive deficits and dementia in parkinson's disease: In: Boller $\mathrm{F}$,
Cappa S. editors. Handbook of Neuropsychology. Amsterdam: Elsevier; 2001:ed: 2, pp 311-71.

18. Martinez-Martin P, Schapira AH, Stocchi F, et al. Prevalence of nonmotor symptoms in Parkinson's disease in an international setting; study using nonmotor symptoms questionnaire in 545 patients. Mov Disord. 2007; 22:1623-9.

19. Oh ES, Lee JH, Seo JG, et al. Autonomic and cognitive functions in Parkinson's disease (PD). Arch of Gerontol Geriatr. 2011; 52:84-8.

20. Magerkurth C, Schnitzer R, Braune S. Symptoms of autonomic failure in Parkinson's disease: prevalence and impact on daily life. Clin Auton Res. 2005; 15:7682.

21. Allcock L. Orthostatic hypotension in Parkinsons disease. ACNR. 2010; 10:51-2.

22. Rowe JB, Hughes L, Ghosh BC, et al. Parkinson's disease and dopaminergic therapy - differential effects on movement reward and cognition. Brain. 2008; 131: 2094-105.

23. Kaye JM, Young TM, Mathias CJ, et al. Neuroendocrine and behavioural responses to $\mathrm{CO} 2$ inhalation in central versus peripheral autonomic failure. Clin Auton Res. 2006; 16:121-9. 